\title{
Evolution of the "Ecology" of the Transport Complex
}

\author{
Alik Chebotaev ${ }^{1}$, Andrey M. Ivakhnenko ${ }^{1 *}$, Vladimir Belyaev ${ }^{1}$, Andrey A. Ivakhnenko $^{1}$, and \\ Ekaterina Faddeeva ${ }^{1}$ \\ ${ }^{1}$ Moscow Automobile and Road Construction State Technical University (MADI), 64 Leningradsky \\ prosp., Moscow, 125319, Russia
}

\begin{abstract}
The article is devoted to the interaction between the transportation sector and the environment in terms of global emission of greenhouse gas $\mathrm{CO}_{2}$ during combustion of various types of motor fuels. We offer a closed-tech recycling $\mathrm{CO}_{2}$ cycle by natural environment without using non-renewable oil fuels. Offered rate principles of green, characterized a complex level of vehicle impact on human environment.
\end{abstract}

\section{Introduction}

Analysis of the global civilization development trends demonstrates that three key factors underlie all economy processes. These are land, labor and capital and, as they transform, they determine interaction between human and environment. They also affect technical and economic, information and environmental processes that are taking place in individual countries, continents and on overall Earth. High development rate of the industrial and agricultural production in various countries as observed in the past thirty years resulted in the more intense use of natural resources and the increased human impact on the habitat, having generated a problem of increasing anthropogenic pressure on the natural ecosystem and the human.

The issues of protection of water and air resources exceeded the states' borders and, in many aspects, acquired a planet-scale nature, due to the economy globalization and transfer of air masses. In many regions of Earth, they are considered negative in terms of interaction between lithosphere, hydrosphere and atmosphere. The search for the way of complete elimination of adverse effects remains an unsolved problem $[1,5]$.

In this sense, the crucial role is played by Kyoto Protocol and, since November 4, 2016, Paris Agreement which is an international act instrumental to making an attempt to influence present climate changes on Earth by limiting its temperature increase to $+2^{\circ} \mathrm{C}$. It intends the use of market mechanisms in order to restrict the greenhouse gases emission and recommends introducing alternative sources, environmental management and emission trading between the countries. For instance, the agreement proposes introducing a "carbon fee" at 15 USD per ton of emissions, which is not feasible for industrial countries.

Further development of our civilization will take place under the influence of modern man-caused consequences where the transport system will also participate. This is due to the

*Corresponding author: ivakhnenko_am@mail.ru 
fact that, while performing its functional operations of conveying passengers and goods/loads, transport continues consuming a substantial amount of primary and recoverable fuel and energy resources and emitting contaminants, toxic substances and carbon dioxide in the process.

In addition to this, vehicles affect the socioeconomic environment in the course of transportation. It has to do with acoustic pressure increase, vibration, road accidents, etc.

Scientists have accumulated a sizable scope of statistic data regarding a close connection between the process of the transport operation functioning and its impact on the socioeconomic environment, aquatic environment, flora, fauna, soil, and air environment with increasing emissions of greenhouse gases.

Lately, the primary focus of ecologists and transport specialists is drawn to the problem of one of the global parameters, namely emissions of greenhouse gas $\mathrm{CO}_{2}$ (During fuel combustion, in addition to $\mathrm{CO}_{2}, \mathrm{~N}_{2} \mathrm{O}$ (nitrous oxide whose equivalent to $\mathrm{CO}_{2}$ is 310 ), $\mathrm{CH}_{4}$ (methane whose equivalent to $\mathrm{CO}_{2}$ is 21 ), $\mathrm{SF}_{6}$ - hexafluoride, hydro- and perfluorocarbons are emitted).

Based on these considerations and taking previous works [2] into account, Figure 1 presents a generated model of mutual impact of the transport complex and environment.

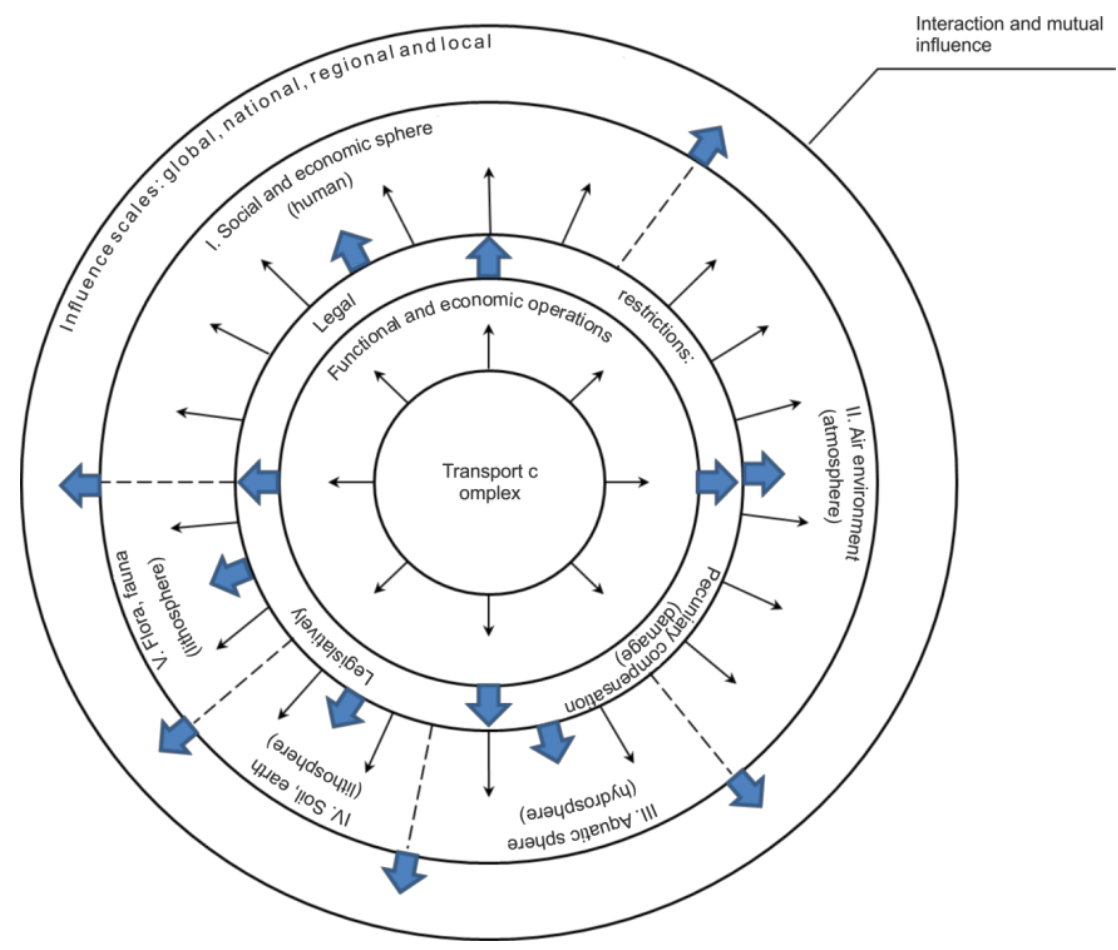

Fig. 1. Interaction between transport complex and environment.

In actual fact, vehicles nowadays consume various fuel types [4] that affect the environment on a global scale in a non-uniform manner. Methodological procedure we have developed makes it possible to perform, whenever necessary, comparative calculations of man-caused emissions of $\mathrm{CO}_{2}$ and extractions of oxygen $\mathrm{O}_{2}$ out of the atmosphere using thermochemical combustion equations as basic data $[2,3]$ (see Table 1). 
Table 1. Thermochemical equations for combustion of motor fuel types that affect the global warming potential.

\begin{tabular}{|c|c|c|c|c|}
\hline \multirow[t]{2}{*}{$\begin{array}{l}\text { Motor fuel } \\
\text { type }\end{array}$} & \multirow[t]{2}{*}{ Thermochemical equation } & \multicolumn{2}{|c|}{$\begin{array}{c}\text { Complete } \\
\text { combustion } \\
\mathrm{kg} / \mathrm{kg} \text { fuel, global }\end{array}$} & \multirow[t]{2}{*}{$\begin{array}{c}\text { Calorific capacity, } \\
\mathrm{mJ} / \mathrm{kg}\end{array}$} \\
\hline & & $\mathrm{CO}_{2}$ & $\mathrm{O}_{2}$ & \\
\hline Gasoline & $2 \mathrm{C}_{8} \mathrm{H}_{18}+9 \mathrm{O}_{2}=16 \mathrm{CO}_{2}+18 \mathrm{H}_{2} \mathrm{O}$ & 3.1 & 3.5 & 44.0 \\
\hline Diesel fuel & $4 \mathrm{C}_{16} \mathrm{H}_{31}+95 \mathrm{O}_{2}=64 \mathrm{CO}_{2}+62 \mathrm{H}_{2} \mathrm{O}$ & 3.16 & 3.4 & 42.1 \\
\hline $\begin{array}{c}\text { Dimethyl } \\
\text { ether }^{*} \\
\text { synthetic fuel }\end{array}$ & $\begin{array}{l}\text { Methanol dehydration: } \\
2 \mathrm{CH}_{3} \mathrm{OH}=\mathrm{CH}_{3} 0 \mathrm{CH}_{3}+\mathrm{H}_{2} \mathrm{O}\end{array}$ & 1.9 & 2.2 & 28.4 \\
\hline $\begin{array}{c}\text { Methane } \\
\text { (compressed) }\end{array}$ & $\mathrm{CH}_{4}+2 \mathrm{O}_{2}=\mathrm{CO}_{2}+2 \mathrm{H}_{2} \mathrm{O}$ & 2.8 & 4.0 & $33.9 \mathrm{~mJ} / \mathrm{m}^{3}$ \\
\hline $\begin{array}{l}\text { Propane } \\
(52 \%) \mathrm{mix}\end{array}$ & $\mathrm{C}_{3} \mathrm{H}_{8}+5 \mathrm{O}_{2}=3 \mathrm{CO}_{2}+4 \mathrm{H}_{2} \mathrm{O}$ & 3.02 & 3.61 & 46.6 \\
\hline $\begin{array}{c}\text { Butane }(48 \%) \\
\operatorname{mix}\end{array}$ & $2 \mathrm{C}_{4} \mathrm{H}_{10}+97 \mathrm{O}_{2}=8 \mathrm{CO}_{2}+10 \mathrm{H}_{2} \mathrm{O}$ & 3.02 & 3.61 & 46.6 \\
\hline Kerosene & $4 \mathrm{C}_{16} \mathrm{H}_{33}+97 \mathrm{O}_{2}=64 \mathrm{CO}_{2}+66 \mathrm{H}_{2} \mathrm{O}$ & 3.15 & 3.32 & 43.0 \\
\hline Ethanol & $\mathrm{C}_{2} \mathrm{H}_{5} \mathrm{OH}+3 \mathrm{O}_{2}=2 \mathrm{CO}_{2}+3 \mathrm{H}_{2} \mathrm{O}$ & 1.9 & 2.1 & 26.8 \\
\hline Methanol & $2 \mathrm{CH}_{3} \mathrm{OH}+3 \mathrm{O}_{2}=2 \mathrm{CO}_{2}+4 \mathrm{H}_{2} \mathrm{O}$ & 1.4 & 1.5 & 20.0 \\
\hline Hydrogen & $2 \mathrm{H}_{2}+\mathrm{O}_{2}=2 \mathrm{H}_{2} \mathrm{O}$ clean burning & - & 8.0 & 121.0 \\
\hline $\begin{array}{c}\text { Coal (at } \\
\text { thermal power } \\
\text { plants) }\end{array}$ & $\mathrm{C}+\mathrm{O}_{2}=\mathrm{CO}_{2}$ & 2.55 & 2.12 & 29.0 \\
\hline
\end{tabular}

*Another technology (Gasto Liguid): $\mathrm{CH}_{4} \rightarrow \mathrm{CO}+\mathrm{H}_{2}=\mathrm{CH}_{3} \mathrm{OCH}_{3}$

It can be seen from the Table 1 data that the "minimal" emission of the global greenhouse gas is observed when such motor fuel types are burned in vehicle motors whose chemical formulas already contain oxygen. Therefore, it is feasible to use the data from this table when developing measures for reduction of $\mathrm{CO}_{2}$ emissions (We should keep in mind here that in Russia, 5.4 ha of "clean" forest vegetation accrues to each resident. $\mathrm{CO}_{2}$ absorption capacity of our forest (or equivalent) is 700 million tons a year with the corresponding emission of $\mathrm{O}_{2}$. In 24 hours, a human consumes about $1 \mathrm{~kg}$ of oxygen "produced" by $25-30 \mathrm{~m}^{2}$ of forest.).

Obviously, those vehicles will be "greener" that use methanol, dimethyl ether, methane and, finally, in the long run, hydrogen as a motor fuel. Overall, from the viewpoint of Earth climate warming, hydrogen is the most acceptable substance to reduce the planet's heating. Full account of the global warming potential in terms of $\mathrm{CH}_{4}$ equals 21 and $\mathrm{N}_{2} \mathrm{O}$ is 310 . Therefore, emission of 1 kilo of methane is equivalent to $21 \mathrm{~kg}$ of $\mathrm{CO}_{2}$ and emission of $1 \mathrm{~kg}$ of nitrous oxide is equivalent to $310 \mathrm{~kg}$ of $\mathrm{CO}_{2}$. It must be taken into consideration when determining a potential volume of greenhouse gas in transport.

For instance, what is the "contribution" a passenger car running on gasoline or diesel fuel makes into the emissions of $\mathrm{CO}_{2}$ ? If we take an "average" gasoline passenger car with a fuel consumption of $7.8 \mathrm{~kg} / 100 \mathrm{~km}$ and an annual mileage of 20 thousand $\mathrm{km}$, then, in line with the Table 1 data, emission of $\mathrm{CO}_{2}$ with complete combustion will be 4,836 $\mathrm{kg}$ per year. The annual emission of $\mathrm{CO}_{2}$ of an urban 2-million-car fleet will amount to as much as 9.7 million tons. This way, introduction of ecological compatibility fuel norms for the newly manufactured passenger cars will enable the fuel consumption and emission of $\mathrm{CO}_{2}$ to be reduced. In some countries, limits on the emissions of $\mathrm{CO}_{2}$ down to $120-145 \mathrm{~g} / \mathrm{km}$ are 
introduced, which is akin to reduction of specific fuel consumption for the manufactured cars down to 5-7 liters per $100 \mathrm{~km}$ (in Lupo system the norm is 3 liters per $100 \mathrm{~km}$ ).

So what future problems of the ambient environment related to the planet's warming lay in store for us? Natural conditions "dictate" us expected depletion of oil, gas, coal and other mineral resources that determine the volume of $\mathrm{CO}_{2}$ emitted during combustion to a great extent. In a long run, a feasible action for the satisfaction of vital needs of the planet's population seems to be the reduction of the risk of adverse environmental effects of $\mathrm{CO}_{2}$ excess in the atmosphere by using closed loops of the actual fuels' production and consumption.

Data in Figure 2 show that implementation of feedback using the plant mass and solar energy will entirely eliminate adverse consequences of energy deficiency and "guarantees" energy survival of the future generations while reducing the risk of Earth's heating. Unfortunately, the problem of harmful emissions of toxic substances into the human habitat remains not quite solved nevertheless. Yet, uranium helps to solve it partially, as in terms of power efficiency, fission of $1 \mathrm{~g}$ of uranium equals burning of 2.5-3 tons of coal at the thermal power plants and corresponding reduction of $\mathrm{CO}_{2}$ emissions down to 7.5-9 tons [6].

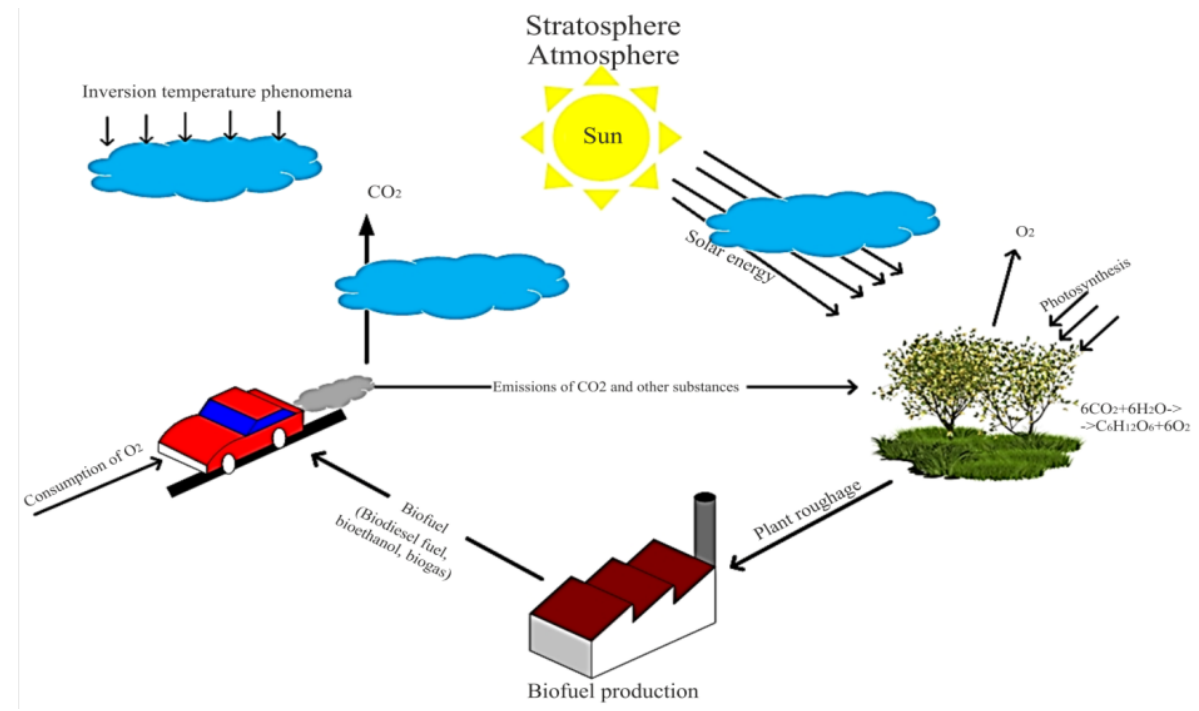

Fig. 2. Man-induced, environmental and transport-related cycling of $\mathrm{CO}_{2}$ in nature.

In addition to the transport impact on the planet's global warming potential, contamination of the human habitat. i.e. the ground layer of atmosphere, is also of importance.

\section{Impact of the transport's toxic emissions of the human habitat (the ground layer of atmosphere)}

The rapidly expanding scale of ecological problems $[8,9]$ in the ground layer of atmosphere in big cities and megalopolises determine the necessity to rate toxic emissions from the employed vehicles, especially motorcars. Nearly $90 \%$ of the harmful substances (hard particles of REE-10, carbonic oxide $\mathrm{CO}$, nitrogen oxides $\mathrm{NO}_{\mathrm{X}}$, carbons $\mathrm{C}_{\mathrm{n}} \mathrm{H}_{\mathrm{m}}$ and sulphur oxides $\mathrm{SO}_{\mathrm{x}}$ ) and ground-level ozone $\mathrm{O}_{3}$ entering the urban ground layer of atmosphere are due to the emissions of the vehicles' exhaust gases. Every 24 hours, 47-50 g of toxic substances are emitted per the country's resident and $45 \%$ of them are emitted by moving, transport sources. 
Naturally, environment and especially operation of motor vehicles determined by the toxic substances' emissions affects the human life cycle and morbidity. Contamination of the urban atmosphere has an impact on the population's illnesses associated with cancerous, pulmonary and ophthalmic complications. There are international ecological standards in compliance with UNECE Regulations No. 83 and 49 with the motorcar full weight of up to $3.5 \mathrm{t}$ and over $3.5 \mathrm{t}$ that are implemented in EU ranging from Euro 0 to Euro 5 and 6 . From 1958 to 2016, the emission norms for CO shrank from 85 to $5.45 \mathrm{~g} / \mathrm{kWh}$ (16 times), $\mathrm{C}_{\mathrm{m}} \mathrm{H}_{\mathrm{n}}$ from 5 to $2.38 \Gamma \mathrm{g} / \mathrm{kWh}$ (21 times) and $\mathrm{NO}_{\mathrm{x}}$ from 17 to $5.0 \mathrm{~g} / \mathrm{kWh}$ (3.4 times). Since 2016, Euro-5 norms are compulsory for all manufactured motorcars and connected with the quality of the motor fuels used.

Based on the global trends analysis, to reduce the negative man-caused impacts on the human and environment, a pressing necessity to develop the following trends remains:

- expansion of the use of alternative fuel types (natural gas and hydrogen at the fuel elements; hybrid engines);

- improvement of powertrains in order to increase their efficiency factor;

- structural upgrade of the vehicles in order to reduce their weight and coefficient of the tire rolling resistance, to enhance the vehicles' aerodynamic properties and ensure their "zero" emission level [10-15];

- fuel efficiency enhancement, i.e. increase of mileage per 1 liter of fuel.

Consolidate data in the context of a differentiated accounting of the efficiency factor of various motor fuels and electric power production and use "on the wheel" is received"). The "greenest" total efficiency is observed in the diesel motor operating on liquefied (0.208) and compressed natural gas (0.203), while the efficiency factor of the fuel operating use is 0.23 . Diesel motorcars with an electric drive (combined power unit vehicles) have a total efficiency factor of 0.181 (with the efficiency factor of the fuel operating use of 0.29). Gasoline cars are characterized by the total "green" efficiency factor of 0.135 (the efficiency factor of the fuel operating use being 0.23 ). The total "green" efficiency factor of the "clean" diesel engine is 0.169 (the efficiency factor of the fuel operating use being 0.27 ). A low total efficiency factor is observed in environmentally "friendly" electric cars - mere 0.161 with the efficiency factor of electric power use "on the wheel" being 0.71 .

It follows from the above data that the most environmentally "green" [10] vehicles in a megalopolis are diesel combined power units with electric drives and vehicles operating on natural gas.

Impact of other transport types on the ground-level atmosphere is quite insignificant. For instance, air transport produces the mass of emitted substance at the height of $914 \mathrm{~m}$ and mostly at the cruising flight height.

The noise (sound level) generated by vehicles must not exceed the medical norm of 84 $\mathrm{dBA}$, including the effect of noise screens, and the noise at the air transport must not exceed $85 \mathrm{dBA}$ and $140 \mathrm{dBA}$ at the take-off. Electromagnetic emanation, acceleration, slowdown and vibrations at various transport types have an insignificant impact on the environment and humans. A high exposure exists in the traffic safety issue that has not been solved yet (over 150 thousand people die in road accidents worldwide) and requires an individual consideration.

\section{General principles of evaluating "greenness" levels in transportation}

We suggest introducing a new scientific integrated notion called "ecological safety" for the overall characteristic under interaction of environment, human and transport in the transport and ecological studies. By "ecological safety" and "greenness" we understand various degrees of the man-caused and socioeconomic impact of the transport on the air and aquatic 
environments, flora, fauna and soil, as well as on the human with a lowest damage. Obviously, the scale of such transport impact is of a local, regional, national and global nature (Figure 1). Therefore, employment of the notion "ecological safety" allows us evaluating the "greenness" degree of the transport type including environmental and global parameters and safety of traffic and flights [7].

To evaluate the level of such an impact, we need to determine criteria with which specialists, political figures and general public could effect monitoring and control the transport's interaction with environment in order to achieve their harmonization and sustainable development. Within the scope of polemics about various methods of evaluation of the vehicles' "greenness" associated with environment and human, we suggest using the organoleptic methodological procedure, i.e. the method of the skilled professionals perceiving subjectively specific properties of toxic substances, noise, traffic safety values and other determinants. It is recommended to employ this method when selecting some solutions in determining the "ecological safety" of transport types or other (at various management levels). As these solutions are weakly structured due to the great number of considered measuring instruments, the organoleptic method is based on the determination of the evaluated criteria package.

To make the comparative calculations easier to perform, we adopt that the specific weight of single-functional criteria for each transport type is the same, while the actual criteria are divided into three qualimetric levels by their impact degree. For instance, we adopt that the following criteria symbols are established to determine the "greenness" level of the employed transport type: one symbol (mark) + means a faint negative impact on the human and environment; symbol (mark) ++ means a moderate interaction; and symbol (mark) +++ means the strongest impact. In the end it turns out that the greater the total mark sum, the lower the "greenness" degree of one transport type or another.

Performed statistical studies, conclusion regarding the study of the transport's mancaused impact, suggested methodological procedure of accounting for multi-aspect data and pervious publications $[1,2,4]$ made it possible to suggest a new level of "greenness" and "ecological safety" of the employed transport types. Obtained data can be used for an efficient solving of future environment-related problems at various transport and environment management levels (Table 2).

Expected unfolding discussions concerning determination of the "greenness" level of vehicles will be the first step towards creation of a comprehensive methodology for accounting of the transport impact on environment and humans.

Analysis of the rated data in Table 2 shows that the "greenest" transport types are its air, oil and oil product pipeline types. Urban electrical transport and railroad transport with an electric drive are "greener". The data in Table 2 proves the importance of the search for a compromise when evaluating the "greenness" and the number of vehicles employed in urban agglomerations.

\section{Conclusions}

Developed methodological procedures to determine "ecological safety" and "greenness" levels of vehicles may be used at various control levels and during implementation and introduction of "Plan - Do - Check - Act" methodology, i.e. planning, performing, checking and acting for any functioning organizations in compliance with the "National standard of the Russian Federation for the environmental management system" [5]. 
Table 2. Level of "greenness" and "ecological safety" of transport types.

\begin{tabular}{|c|c|c|c|c|c|c|c|c|c|c|c|c|c|c|}
\hline \multirow[b]{2}{*}{ 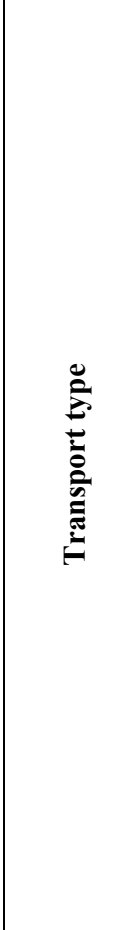 } & \multicolumn{3}{|c|}{ Global parameters } & \multicolumn{6}{|c|}{$\begin{array}{l}\text { Impact on the atmosphere } \\
\text { (human habitat) }\end{array}$} & \multicolumn{2}{|c|}{$\begin{array}{c}\text { Impact on } \\
\text { the } \\
\text { socioecono } \\
\text { mic sphere }\end{array}$} & \multirow[b]{2}{*}{ 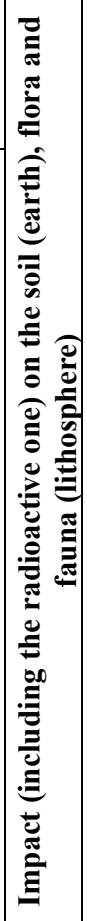 } & \multirow[b]{2}{*}{ 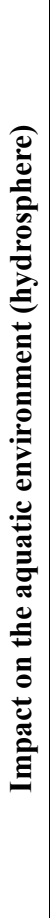 } & \multirow[b]{2}{*}{ 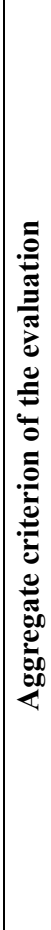 } \\
\hline & 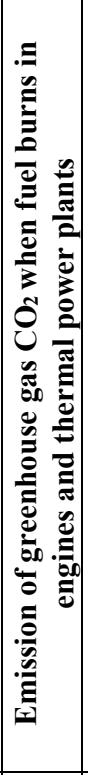 & 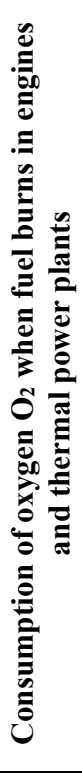 & 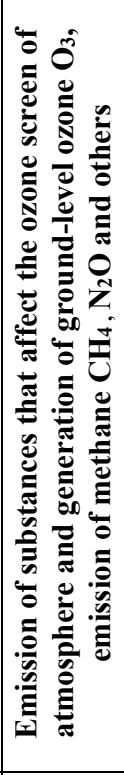 & 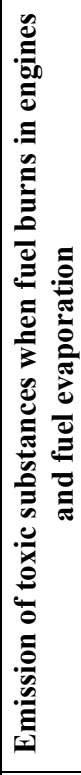 & 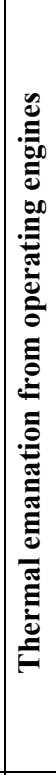 & 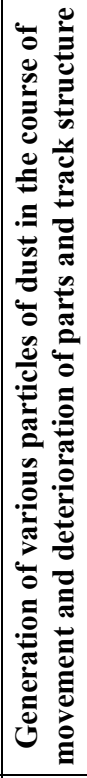 & 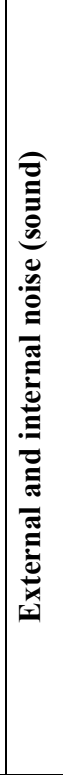 & 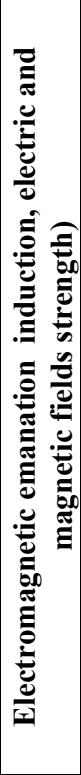 & 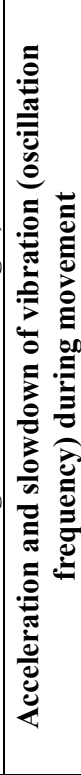 & 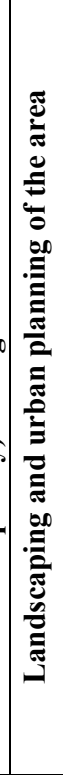 & 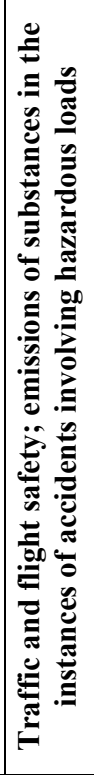 & & & \\
\hline $\begin{array}{c}\text { Motor } \\
\text { vehicle } \\
\text { transport }\end{array}$ & +++ & +++ & + & +++ & + & + & ++ & ++ & ++ & ++ & +++ & +++ & + & 27 \\
\hline $\begin{array}{c}\text { Railroad } \\
\text { transport }\end{array}$ & $\left.+^{*}\right)$ & $\left.+^{*}\right)$ & + & $\left.+{ }^{*}\right)$ & + & + & ++ & + & ++ & + & ++ & ++ & + & 17 \\
\hline $\begin{array}{c}\text { Air } \\
\text { transport }\end{array}$ & ++ & ++ & + & ++ & + & - & +++ & + & ++ & - & + & ++ & + & 18 \\
\hline $\begin{array}{c}\text { Urban } \\
\text { electrical } \\
\text { transport }\end{array}$ & $\left.+^{*}\right)$ & $\left.+^{*}\right)$ & - & $\left.+^{*}\right)$ & + & + & + & ++ & ++ & + & + & + & - & 13 \\
\hline $\begin{array}{c}\text { Inland } \\
\text { water } \\
\text { transport }\end{array}$ & + & + & + & + & + & - & + & + & + & - & + & - & ++ & 11 \\
\hline $\begin{array}{l}\text { Gas } \\
\text { pipeline } \\
\text { transport }\end{array}$ & $\left.++^{*}\right)$ & $\left.++^{*}\right)$ & + & $\left.+^{*}\right)$ & + & - & + & + & - & - & - & + & - & 10 \\
\hline $\begin{array}{l}\text { Oil and } \\
\text { oil } \\
\text { product } \\
\text { pipeline } \\
\text { transport }\end{array}$ & $\left.+^{*}\right)$ & $\left.+^{*}\right)$ & - & $\left.+{ }^{*}\right)$ & + & - & - & + & - & - & - & ++ & - & 7 \\
\hline $\begin{array}{c}\text { Sea } \\
\text { transport }\end{array}$ & + & + & + & + & + & - & + & + & + & - & + & - & ++ & 11 \\
\hline
\end{tabular}

${ }^{*}$ With consideration to the electric power production at the thermal power plants

Marking rate of "greenness": + means a faint impact on the human and environment; ++ means a moderate impact; +++ means a strong impact. 
The suggested methodology will be eventually conductive to the formation of the future intelligence environment called noosphere (according to V.I. Vernadsky) as one of the constituent elements of the sustainable social development. "Solar drive" seems promising as well.

Naturally, further socioeconomic development depends significantly on the achieved levels of ecological compatibility of the transportation system determining the emissions into the human habitat. It seems reasonable to develop a new act "Purification of atmospheric air in the ground layer" where the quality factor would be established on the basis of the natural scope of consumption by urban population at 5-10 liters of air per minute.

\section{References}

1. A.A. Chebotaev, Fuel and environmental problems of the transport complex development / A.A. Chebotaev, S.S. Ushakov // Pipes of NIIKTP of the Ministry of economy of the Russian Federation. Issue 137 (1992)

2. A.A. Chebotaev, Genesis of the "economy pendulum" in the controlled market relations. M., Kolos, (2003)

3. Management of environmental protection in transport. Issue 2 NIIAT, M., (2000)

4. Alternative sources of energy for the transport and power economy of big cities. Collection of reports. Part 1 M., Prima - Press - M., (2005)

5. GOST R ISO 14001-2007. Environmental management systems. Requirements and guidelines". "National standard of the Russian Federation for the environmental management system" (2007)

6. $\mathrm{CO}_{2}$ Emissions from fuel combustion. Paris: IEA (2016)

7. Rosstat. Russia in numbers. (2016)

8. Transport and logistics in the Arctic Region. Almanac. 2016. Issue 2. M.: Tekhnosfera

9. Lukanin, V.N., Trofimenko Yu.V. Industrial and transport ecology. M.: Vyssh. Shkola, (2001)

10. A.A. Chebotaev, Environmental and energy efficiency of passenger services in a megalopolis / A.A. Chebotaev, D.B. Efimenko, A.M. Ivakhnenko, V.V. Oshorova // Motor vehicle enterprises. \#4 (2016)

11. A.B. Nikolaev, Analysis of the Incident Detection Technologies and Algorithms in Intelligent Transport Systems / A.B. Nikolaev, A.M. Ivakhnenko, Y.S. Sapego, T.E. Mel'nikova, V.Y. Stroganov // International Journal of Applied Engineering Research ISSN 0973-4562 Volume 12, Number 15 pp. 4765-4774 (2017)

12. D.B. Efimenko, Simulation of Automatic Incidents Detection Algorithm on the Transport Network / D.B. Efimenko, A.A. Ivakhnenko, A.M. Ivakhnenko, K. Nakova // International Science Conference, High technology. Business. Society/ - Bulgary, Borovets. (2017).

13. A.B. Nikolaev, Simulation of Automatic Incidents Detection Algorithm on the Transport Network / A.B. Nikolaev, A.M. Ivakhnenko, Y.S. Sapego, A.N. Jakubovich, L.I. Berner // International Journal of Environmental and Science Education (IJESE) Volume 11, Issue 16, pp. 9060-9078 (2016)

14. A.A. Chebotaev, Noosphere: interaction of transport, nature and man in in a megalopolis / A.A. Chebotaev, A.A. Ivakhnenko, A.M. Ivakhnenko // Journal "Freight and passenger motor transport". \#7 (2015) 
15. A.A. Chebotaev, Research the efficiency of transportation mobility of residents in megapolis using various modes of transport on urban routes / A.A. Chebotaev, A.A. Ivakhnenko, A.M. Ivakhnenko, V.V. Oshorova // International science conference «Science and Practice: new Discoveries» Russia, Moscow - Czech Republic, Karlovy Vary (2015) 